\title{
Keputusan Keuangan dan Good Corporate Governance terhadap Kinerja Dimoderasi Ukuran Perusahaan
}

\author{
Ainun Jariah \\ Program Studi Manajemen, STIE Widya Gama Lumajang \\ anjar040820@gmail.com
}

\begin{abstract}
Abstrak
Kinerja keuangan yang optimal merupakan tujuan perusahaan yang dapat dicapai melalui pelaksanaan fungsi manajemen keuangan. Salah satu cara untuk meningkatkan kinerja perusahaan selain keputusan keuangan adalah dengan melaksanakan good corporate governance. Penelitian ini bertujuan untuk mengetahui pengaruh keputusan manajemen keuangan dan good corporate governance, secara parsial maupun simultan terhadap kinerja keuangan dengan ukuran perusahaan sebagai pemoderasi manufaktur di Indonesia. Jumlah sampel adalah 37 perusahaan manufaktur yang rutin mempublikasikan laporan keuangan periode 2014 - 2017. Dengan menggunakan teknik analisis regresi linier berganda dan moderasi, maka hasil penelitian menunjukkan bahwa secara parsial keputusan pendanaan dan good corporate governance secara signifikan terhadap kinerja keuangan. Hanya keputusan investasi yang berpengaruh parsial signifikan terhadap ukuran perusahaan. Keputusan investasi, keputusan pendanaan, kebijakan dividen dan good corporate governance secara simultan signifikan berpengaruh terhadap baik terhadap ukuran perusahaan maupun kinerja keuangan. Dan ukuran perusahaan bukan pemoderasi pengaruh keputusan keuangan dan good corporate governance terhadap kinerja keuangan.
\end{abstract}

Kata Kunci: Good Corporate Governance, Keputusan Keuangan, Kinerja Keuangan, Ukuran Perusahaan.

\begin{abstract}
Optimal financial performance is a company goal that can be achieved through the implementation of financial management functions. One way to improve company performance in addition to financial decisions is to implement good corporate governance. This study aims to determine the effect of financial management decisions and good corporate governance, partially or simultaneously on financial performance with the size of the company as moderating manufacturing in Indonesia. The number of samples is 37 manufacturing companies that routinely publish financial statements for the period 20142017. Using multiple linear regression analysis and moderation techniques, the results of the study show that partially funding decisions and good corporate governance significantly affect financial performance. Only investment decisions that have a significant partial effect on the size of the company. Investment decisions, funding decisions, dividend policies and good corporate governance simultaneously have a significant effect on both company size and financial performance. And the size of the company does not moderate the influence of financial decisions and good corporate governance on financial performance.
\end{abstract}

Keywords: Good Corporate Governance, Financial Decisions, Financial Performance, Company Size. 


\section{PENDAHULUAN}

Kinerja keuangan merupakan patokan utama untuk mengukur baik atau tidaknya kinerja perusahaan, hal tersebut dapat dilihat dari laporan keuangannya. Mengukur kinerja keuangan perusahaan dapat diketahui melalui dua sisi yaitu: sisi internal perusahaan dengan melihat laporan keuangan dan sisi eksternal perusahaan yaitu nilai perusahaan dengan cara menghitung kinerja keuangan perusahaan (Nofitasari, Kertahadi, and Yaningwati 2016). Kinerja keuangan yang optimal merupakan tujuan perusahaan yang dapat dicapai melalui pelaksanaan fungsi manajemen keuangan. Manajemen keuangan menyangkut penyelesaian atas keputusan penting yang diambil perusahaan, antara lain keputusan investasi, keputusan pendanaan, dan kebijakan dividen. Kombinasi optimal atas ketiganya akan memaksimumkan nilai perusahaan (Argo n.d.). Harmono (2016:9) mengemukakan bahwa investasi modal sebagai aspek utama kebijakan manajemen keuangan karena investasi adalah bentuk alokasi modal yang realisasinya harus menghasilkan manfaat atau keuntungan di masa yang akan datang. Di sisi lain, manfaat investasi di masa yang akan datang diliputi oleh ketidakpastian, yang dalam konsep manajemen keuangan disebut risiko invstasi. Sebagai konsekuensi, dalam melakukan investasi harus melaui proses evaluasi secara cermat mengenai prediksi tingkat keuntungan dan resiko. Menurut signaling theory, pengeluaran investasi memberikan sinyal positif mengenai pertumbuhan perusahaan di masa yang akan datang, sehingga dapat meningkatkan harga saham. Artinya keputusan investasi yang dilakukan perusahaan diharapkan mampu memberi sinyal positif mengenai pertumbuhan pendapatan di masa mendatang. Pendapat tersebut diatas mendukung penelitian yang dilakukan oleh Hsiao dan Hsu (2011) dengan hasil penelitian terdapat hubungan yang positif antara investment opportunity set dan kinerja perusahaan.

Keown et al., (2008:121), mengemukakan bahwa kebijakan hutang adalah kebijakan yang dilakukan perusahaan untuk mendanai operasinya dengan menggunakan hutang keuangan atau yang biasa disebut dengan finansial leverage atau leverage keuangan. Leverage keuangan adalah praktek pendanaan sebagian aktiva perusahaan dengan sekuritas yang menanggung beban pengembalian tetap dengan harapan bisa meningkatkan pengembalian akhir bagi pemegang saham (Keown et al. 2008). Keputusan pendanaan sangat mempengaruhi perolehan laba perusahaan, jika pendanaan berasal dari eksternal maka perusahaan akan menanggung biaya modal, sedangkan jika berasal dari internal maka perusahaan harus menanggung dividen untuk investor. Pendapat ini didukung oleh Tajang (2011) dengan hasil penelitian leverage memiliki pengaruh penting dan memiliki hubungan positif terhadap profitabilitas. Akan tetapi bertentangan dengan Innocent, dkk. (2014) yang hasil penelitiannya menunjukkan bahwa leverage keuangan berpengaruh negative tidak signifikan terhadap kinerja keuangan untuk return on assets.

Harmono (2016:12-13) mengemukakan bahwa menurut Van Horne (1980), kebijakan penting ketiga dalam manajemen keuangan adalah kebijakan dividen. Kebijakan dividen adalah presentase laba yang dibayarkan kepada para pemegan saham dalam bentuk dividen tunai, penjagaan stabilitas dividen dari waktu ke waktu, pembagian dividen saham, dan kembalian kembali saham. Rasio pembayaran dividaen (dividend pay out ratio), ikut menentukan besarnya jumlah laba yang ditahan perusahaan harus dievaluasi dalam kerangka tujuan pemaksimalan kekayaan para pemegang saham. Distribusi kepada pemegang saham bisa berupa uang tunai ataupun saham. Baik berupa uang tunai atau saham tergantung pada tingkat laba. Pembayaran dividen biasanya dipenuhi dari pendapatan dan arus kas (Azeez dan Latifat, 2015). Divident payout tinggi adalah indikasi dan bukti jelas bahwa perusahaan memperoleh hasil dari kegiatan operasinya (Azeez dan Latifat, 2015). 
Divident payout yang tinggi menunjukkan kepercayaan manajemen dalam stabilitas dan pertumbuhan laba masa depan sedangkan divident payout yang rendah menunjukkan bahwa manajemen tidak yakin dengan stabilitas laba dan keberlanjutan pertumbuhan laba (Azeez dan Latifat, 2015). Pendapat tersebut di atas didukung oleh A. Ajanthan (2013) dengan hasil penelitian menunjukkan bahwa terdapat hubungan yang positif antara dividend policy dan profitabilitas perusahaan (Ajanthan 2013). Adediran dan Alade (2013) hasil penelitian menunjukkan bahwa terdapat hubungan yang positif signifikan antara kebijakan dividend dan profitabilitas organisasi (Adediran and Alade 2013). Ng'ang'a dan Kiuru (2014) dengan hasil penelitian menunjukkan bahwa terdapat hubungan antara dividen dan kinerja perusahaan (Ng'ang'a, Kiuru 2014). Sedangkan Hassan, dkk. (2015) melakukan penelitian pada perusahaan energy dan tekstil di Pakistan periode 1996 - 2008, dengan hasil penelitian bahwa dividend payout ratio berpengaruh negatif terhadap profitabilitas.

Salah satu cara untuk meningkatkan kinerja perusahaan/organisasi adalah dengan melaksanakan tata kelola perusahaan yang baik yang biasa disebut dengan good corporate governance. Corporate governanace merupakan salah satu elemen kunci dalam meningkatkan efesiensi ekonomis, yang meliputi serangkaian hubungan antara manajemen perusahaan, dewan komisaris, para pemegang saham dan stakeholders lainnya (Kurniawan 2012). Struktur corporate governance membagi hak dan tanggung jawab dari masing-masing anggota yang berpartisipasi dalam sebuah perusahaan seperti pimpinan, manajer, pemegang saham, dan pemangku kepentingan lainnya melalui aturan dan prosedur untuk pengambilan keputusan yang berkaitan dengan kegiatan perusahaan. Melalui struktur yang ada tujuan perusahaan dapat diatur dan dicapai, dan pengawasan kinerja dapat dilakukan (Saifi, dkk., 2013). Hassan dan Ahmed (2012) meneliti perusahaan di Nigeria periode 2008 - 2010, dengan hasil penelitian yang menyatakan bahwa good corporate governance berpengaruh terhadap kinerja perusahaan. Mirza dan Javed (2013) meneliti 60 perusahaan Pakistan yang terdaftar Bursa Efek Karachi, dengan hasil penelitian good corporate governance berpengaruh terhadap kinerja keuangan. Putra dan Simanungkalit (2014) menggunakan Perusahaan perbankan yang terdaftar di Bursa Efek Indonesia periode 2008 - 2012, hasil penelitian menunjukkan bahwa good corporate governance berpengaruh terhadap kinerja perbankan. Tetapi hasil penelitian Brown dan Caylor (2009) meneliti pada 2.327 perusahaan, hasil penelitian menunjukkan bahwa semua komponen good corporate governance tidak memiliki pengaruh signifikan terhadap kinerja operasi perusahaan. Jannati, dkk. (2014) meneliti perusahaan sector perbankan yang terdaftar di Bursa Efek Indonesia, hasil penelitian menunjukkan bahwa tata kelola dengan menggunakan proxy kepemilikan institusional dan jumlah dewan direksi berpengaruh positif tidak signifikan terhadap kinerja keuangan.

Kinerja keuangan perusahaan juga dipengaruhi oleh ukuran perusahaan. Sawitri, dkk (2017) menyatakan bahwa ukuran perusahaan menggambarkan besar kecilnya suatu perusahaan, besar kecilnya ukuran perusahaan dapat ilihat dari besarnya asset perusahaan. Semakin besar ukuran perusahaan, maka semakin besar profitabilitas untuk meningkatkan laba, semakin maksimal aktiva perusahaan maka laba yang didapat menjadi maksimal pula (Keuangan et al. 2017). Tetapi pendapat ini bertentangan dengan Epi (2016) yang menyatakan bahwa ukuran perusahaan tidak berpengaruh terhadap kinerja keuangan (No Title 2016), selain itu juga Isbanah (2015) yang menyatakan bahwa ukuran perusahaan tidak berpengaruh terhadap ROE (Isbanah 2015). Hal ini menunjukkan bahwa ukuran perusahaan bukan jaminan bahwa perusahaan akan meiliki kinerja yang baik. Berdasarkan uraian tersebut diatas, maka peneliti ingin membuktikan peranan keputusan keuangan dan good corporate governance pengaruhnya terhadap kinerja keuangan diperkuat ataukah tidak oleh ukuran perusahaan. 
Berdasar penjelasan tersebut, maka hipotesis dalam penelitian ini adalah sebagai berikut:

H1 : Terdapat pengaruh keputusan keuangan dan good corporate governance secara parsial signifikan terhadap kinerja keuangan.

H2 : Terdapat pengaruh keputusan keuangan dan good corporate governance secara simultan signifikan terhadap kinerja keuangan.

H3 : Terdapat pengaruh keputusan keuangan dan good corporate governance secara parsial signifikan terhadap ukuran perusahaan.

H4 : Terdapat pengaruh keputusan keuangan dan good corporate governance secara simultan signifikan terhadap ukuran perusahaan.

H5 : Ukuran perusahaan memoderasi keputusan keuangan dan good corporate governance secara signifikan terhadap kinerja keuangan.

Berdasar latar belakang dan hipotesis yang diajukan, maka tujuan dalam penelitian ini adalah : a) Untuk menganalisis pengaruh keputusan keuangan dan good corporate governance secara parsial signifikan terhadap kinerja keuangan. b) Untuk menganalisis pengaruh keputusan keuangan dan good corporate governance secara simultan signifikan terhadap kinerja keuangan. c) Untuk menganalisis pengaruh keputusan keuangan dan good corporate governance secara parsial signifikan terhadap ukuran perusahaan. d) Untuk menganalisis pengaruh keputusan keuangan dan good corporate governance secara simultan signifikan terhadap ukuran perusahaan. e) Untuk menganalisis ukuran perusahaan memoderasi keputusan keuangan dan good corporate governance secara signifikan terhadap kinerja keuangan.

\section{METODE PENELITIAN}

Penelitian ini termasuk jenis penelitian survei (survey research). Tujuan penelitian ini bersifat eksplanatori (explanatory research) dan prediksi. Berdasarkan sifatnya, penelitian ini bersifat eksploratif karena pengujian lebih lanjut atas suatu penelitian. Populasi dalam penelitian ini adalah perusahaan manufaktur yang terdaftar di Bursa Efek Indonesia, periode 2014 - 2017, yang keseluruhan berjumlah 555. Pengambilan sampel dilakukan dengan metode purposive sampling. Kriteria perusahaan manufaktur yang dapat dijadikan sampel penelitian ini adalah : a) Perusahaan manufaktur yang listed di Bursa Efek Indonesia pada periode penelitian minimal sejak tahun 2012. b) Perusahaan yang pada periode penelitian tidak melaksanakan akuisisi dan merger. c) Laporan keuangan perusahaan menggunakan satuan uang yang sama selama periode penelitian.

Sesuai dengan kriteria tersebut, maka perusahaan yang lolos seleksi berjumlah 37 buah. Periode penelitian 4 (empat) tahun, 4 x $37=148$, sehingga jumlah sampel dalam penelitian ini adalah 148. Teknik analisis data dalam penelitian ini akan dilakukan dengan menggunakan Moderated Regression Analysis (MRA) atau uji interaksi dengan aplikasi SPSS. Dengan mempertimbangkan pula uji asumsi klasik/pengujian asumsi dasar untuk memenuhi kaidahkaidah dalam model regresi yang telah dirancang dalam penelitian ini.

Pengujian Asumsi Klasik. Asumsi - asumsi klasik sebagai berikut : 1) Variabel bebas dan variabel dependen memiliki hubungan yang linier (garis lurus). 2) Variabel dependen harus kontinyu dan setidaknya berupa skala interval. Variasi dari perbedaan antara aktual dan nilai prediksi harus sama untuk semua nilai prediksi harus sama untuk semua nilai prediksi $\mathrm{Y}$. Artinya, nilai (Y-Y') harus sama untuk semua nilai $Y^{\prime}$. Jika hal ini terjadi, perbedaan menurut 'homoscedasticity'. Selain itu, nilai residual atau ( $\mathrm{Y}-\mathrm{Y}$ ') harus terdistribusi secara normal dengan rata - rata nol. 3) Nilai observasi yang berurutan dari variabel dependen harus tidak 
berhubungan (tidak berkolerasi). Pelanggaran terhadap asumsi disebut "autocorrelation" atau "otokorelasi". Otokorelasi sering terjadi jika data yang dikumpulkan pada suatu periode waktu (time series data). 4) Variabel independen tidak boleh berkorelasi dengan variabel independen lain dalam model. Jika variabel - veriabel independen berkorelasi tinggi (positif maupun negatif), disebut "multicollinearity".

Analisis Regresi Moderasi. Variabel keputusan keuangan (keputusan investasi, keputusan pendanaan, dan kebijakan dividen) dan good corporate governance secara parsial dan simultan terhadap kinerja keuangan menggunakan analisis regresi linier sederhana. Sedangkan untuk menguji pengaruh interaksi dari variabel moderat ukuran perusahaan yang mendukung keputusan keuangan dan good corporate governance terhadap kinerja keuangan digunakan Moderated Regression Analysis (MRA) (Ghozali, 2013; 229).

Persamaan regresi yang diajukan berdasarkan model penelitian adalah sebagai berikut: $\mathrm{NPM}=\sigma+\beta 1 \mathrm{MVE} / \mathrm{BE}+\beta 2 \mathrm{TIE}+\beta 3 \mathrm{DPR}+\beta 4 \mathrm{GCG}+\beta 5 \mathrm{SIZE}$

\section{HASIL DAN PEMBAHASAN}

Perusahaan manufaktur yang dijadikan populasi adalah seluruh perusahaan manufaktur yang terdaftar di Bursa Efek Indonesia sampai dengan tahun 2017. Setelah dilakukan pengambilan sampel dengan menggunakan kriteria tertentu, maka dari 555 perusahaan hanya 37 perusahaan yang bisa dijadikan sampel penelitian.

\section{Hasil Analisis Data}

Persamaan regresi yang dihasilkan adalah sebagai berikut:

$\mathrm{NPM}=-123+2.183 \mathrm{E}-6 \mathrm{MVE} / \mathrm{BE}+1.393 \mathrm{E}-5 \mathrm{TIE}-0.001 \mathrm{DPR}+0.004 \mathrm{GCG}+0.007 \mathrm{SIZE}$

\section{Hasil Uji Asumsi Dasar}

Hasil Uji Normalitas. Pengujian normalitas dilakukan terhadap residual regresi. Pengujian dilakukan dengan menggunakan grafik P-P Plot. Hasil pengujian normalitas data menunjukkan adanya pola grafik yang normal dimana titik-titik berada tidak jauh dari garis diagonal, hal ini berarti bahwa model regresi tersebut sudah berdistribusi normal.

Hasil Uji Multikolinieritas. "Suatu variabel menunjukkan gejala multikolinieritas bisa dilihat dari nilai VIF (Variance Inflation Factor) yang tinggi pada variabel-variabel bebas suatu model regresi. Nilai VIF yang lebih besar dari 10 menunjukkan adanya gejala multikolinieritas dalam model regresi. Hasil pengujian menunjukkan bahwa semua variabel yang digunakan sebagai prediktor model regresi menunjukkan nilai VIF yang cukup kecil, dimana semuanya berada di bawah 10 dan nilai tollerance lebih dari 0,1 . Hal ini berarti bahwa variabel bebas yang digunakan dalam penelitian tidak menunjukkan adanya gejala multikolinieritas, yang berarti bahwa semua variabel independen dalam penelitian ini adalah variabel yang saling independen.

Hasil Uji Autokorelasi. Penggunaan uji autokorelasi adalah untuk melihat apakah ada hubungan linier antara error serangkaian observasi yang diurutkan menurut waktu (data time series). Berdasarkan hasil uji. Maka dapat disimpulkan model regresi yang dihasilkan pada penelitian ini bebas dari autokorelasi.

Hasil Uji Heteroskedastisitas. Pengujian heteroskedastisitas dilakukan dengan menggunakan Scatter Plot. Jika tidak terdapat variabel yang signifikan maka dapat disimpulkan tidak 
adanya masalah heteroskedastisitas. Hasil pengujian heteroskedastisitas menunjukkan tidak terdapat pola yang jelas dari titik-titik tersebut. Hal ini menunjukkan bahwa model regresi tidak memiliki gejala adanya heteroskedastisitas, yang berarti bahwa tidak ada gangguan yang berarti dalam model regresi ini.

Hasil Pengujian Analisis Moderasi. Untuk menguji pengaruh interaksi dari variabel moderat ukuran perusahaan yang mendukung keputusan keuangan dan good corporate governance terhadap kinerja keuangan digunakan uji residual. Berdasarkan uji residual menunjukkan bahwa nilai koefisien parameter dari kinerja keuangan sebesar -2,771 dengan tingkat signifikansi 0,258 jauh di atas 0,05. Hal ini berarti bahwa variabel ukuran perusahaan bukan pemoderasi antara keputusan keuangan dan good corporate governance terhadap kinerja keuangan.

\section{Hasil Pengujian Hipotesis}

Pengujian Hipotesis 1. Pengujian hipotesis secara parsial atau individu untuk masing-masing variabel sebagai berikut: a) Pengaruh keputusan investasi (X1) terhadap kinerja keuangan (Y). Diperoleh nilai t hitung sebesar 1,050 dengan tingkat signifikan 0,295 berarti $t_{\text {hitung }}(1,050)<$ $\mathrm{t}_{\text {tabel }}(1,976)$ dan sig $(0,295)>\alpha(0,05)$ maka $\mathrm{H}_{\mathrm{a}}$ ditolak dan $\mathrm{H}_{0}$ diterima, sehingga dapat disimpulkan bahwa keputusan investasi $\left(\mathrm{X}_{1}\right)$ berpengaruh tidak signifikan terhadap kinerja keuangan (Y). b) Pengaruh keputusan pendanaan (X2) terhadap kinerja keuangan (Y). Diperoleh nilai t hitung sebesar 2,394 dengan tingkat signifikan 0,018 berarti $t_{\text {hitung }}(2,394)>$ $\mathrm{t}_{\text {tabel }}(1,976)$ dan sig $(0,018)<\alpha(0,05)$ maka $\mathrm{H}_{\mathrm{a}}$ diterima dan $\mathrm{H}_{0}$ ditolak, sehingga dapat disimpulkan bahwa keputusan pendanaan $\left(\mathrm{X}_{2}\right)$ berpengaruh signifikan terhadap kinerja keuangan (Y). c) Pengaruh kebijakan dividen (X3) terhadap kinerja keuangan (Y). Diperoleh nilai $\mathrm{t}$ hitung sebesar $-0,332$ dengan tingkat signifikan 0,740 berarti $\mathrm{t}$ hitung $(-0,332)<\mathrm{t}$ tabel $(1,976)$ dan sig $(0,740)>\alpha(0,05)$ maka $\mathrm{H}_{\mathrm{a}}$ ditolak dan $\mathrm{H}_{0}$ diterima, sehingga dapat disimpulkan bahwa kebijakan dividen $\left(\mathrm{X}_{3}\right)$ berpengaruh tidak signifikan terhadap kinerja keuangan (Y). d) Pengaruh good corporate governance (X4) terhadap kinerja keuangan (Y). Diperoleh nilai t hitung sebesar 1,667 dengan tingkat signifikan 0,098 berarti $t_{\text {hitung }}(1,667)<$ $\mathrm{t}_{\text {tabel }}(1,976)$ dan $\operatorname{sig}(0,098)>\alpha(0,05)$ maka $\mathrm{H}_{\mathrm{a}}$ ditolak dan $\mathrm{H}_{0}$ diterima, tetapi pada tingkat $\alpha$ $=10 \%(0,10)$, diperoleh $t_{\text {tabel }}=1,655$. Berarti $t_{\text {hitung }}(1,667)>t_{\text {tabel }}(1,655)$ dan sig $(0,098)<$ $\alpha(0,10), \mathrm{H}_{\mathrm{a}}$ diterima dan $\mathrm{H}_{0}$ ditolak sehingga dapat disimpulkan bahwa good corporate governance $\left(\mathrm{X}_{4}\right)$ berpengaruh signifikan terhadap kinerja keuangan $(\mathrm{Y})$.

Pengujian Hipotesis 2. Dari hasil pengujian diperoleh nilai $F$ hitung sebesar 2,589 dengan tingkat signifikan 0,039 berarti $F_{\text {hitung }}(2,589)>F_{\text {tabel }}(2,43)$ dan sig $(0,039)<\alpha(0,05)$ maka $\mathrm{H}_{\mathrm{a}}$ diterima dan $\mathrm{H}_{0}$ ditolak, sehingga dapat disimpulkan bahwa terdapat pengaruh keputusan keuangan dan good corporate governance yang signifikan secara simultan terhadap kinerja keuangan.

Pengujian Hipotesis 3. Pengujian hipotesis secara parsial atau individu untuk masing-masing variabel sebagai berikut: a) Pengaruh keputusan investasi (X1) terhadap ukuran perusahaan (Z). Diperoleh nilai t hitung sebesar $-8,357$ dengan tingkat signifikan 0,000 berarti $-\mathrm{t}$ hitung ($8,357)<-t_{\text {tabel }}(-1,976)$ dan sig $(0,000)<\alpha(0,05)$ maka $\mathrm{H}_{\mathrm{a}}$ diterima dan $\mathrm{H}_{0}$ ditolak, sehingga dapat disimpulkan bahwa keputusan investasi $\left(\mathrm{X}_{1}\right)$ berpengaruh signifikan terhadap ukuran perusahaan (Z). b) Pengaruh keputusan pendanaan (X2) terhadap ukuran perusahaan (Z). Diperoleh nilai $t$ hitung sebesar 0,050 dengan tingkat signifikan 0,960 berarti $\mathrm{t}_{\text {hitung }}(0,050)<\mathrm{t}$ tabel $(1,976)$ dan sig $(0,960)>\alpha(0,05)$ maka $\mathrm{H}_{\mathrm{a}}$ ditolak dan $\mathrm{H}_{0}$ diterima, sehingga dapat disimpulkan bahwa keputusan pendanaan $\left(\mathrm{X}_{2}\right)$ berpengaruh tidak signifikan terhadap ukuran perusahaan (Z). c) Pengaruh kebijakan dividen (X3) terhadap ukuran 
perusahaan $(Z)$. Diperoleh nilai t hitung sebesar $-0,150$ dengan tingkat signifikan 0,881 berarti $-\mathrm{t}_{\text {hitung }}(-0,332)>-\mathrm{t}$ tabel $(-1,976)$ dan sig $(0,740)>\alpha(0,05)$ maka $\mathrm{H}_{\mathrm{a}}$ ditolak dan $\mathrm{H}_{0}$ diterima, sehingga dapat disimpulkan bahwa kebijakan dividen $\left(\mathrm{X}_{3}\right)$ berpengaruh tidak signifikan terhadap ukuran perusahaan $(Z)$. d) Pengaruh good corporate governance (X4) terhadap ukuran perusahaan $(Z)$. Diperoleh nilai t hitung sebesar 1,513 dengan tingkat signifikan 0,133 berarti $\mathrm{t}_{\text {hitung }}(1,513)<\mathrm{t}$ tabel $(1,976)$ dan sig $(0,133)>\alpha(0,05)$ maka $\mathrm{H}_{\mathrm{a}}$ ditolak dan $\mathrm{H}_{0}$ diterima sehingga dapat disimpulkan bahwa good corporate governance $\left(\mathrm{X}_{4}\right)$ berpengaruh tidak signifikan terhadap ukuran perusahaan (Z).

Pengujian Hipotesis 4. Dari hasil pengujian diperoleh nilai $\mathrm{F}$ hitung sebesar 17,098 dengan tingkat signifikan 0,000 berarti $F$ hitung $(17,098)>F$ tabel $(2,43)$ dan sig $(0,000)<\alpha(0,05)$ maka $\mathrm{H}_{\mathrm{a}}$ diterima dan $\mathrm{H}_{0}$ ditolak, sehingga dapat disimpulkan bahwa terdapat pengaruh keputusan keuangan dan good corporate governance yang signifikan secara simultan terhadap ukuran perusahaan.

Pengujian Hipotesis 5. Dari hasil analisis moderasi diperoleh nilai koefisien parameter kinerja keuangan sebesar $-2,771$ dengan signifikansi 0,258 . Karena signifikansinya $(0,258)>\alpha$ $(0,05)$, maka $\mathrm{H}_{\mathrm{a}}$ ditolak dan $\mathrm{H}_{0}$ diterima. Sehingga dapat disimpulkan ukuran perusahaan bukan merupakan varibel pemoderasi.

\section{Pembahasan}

Pembahasan ini berkaitan dengan hasil pengujian terhadap hipotesis pertama yang menyatakan bahwa terdapat pengaruh keputusan keuangan dan good corporate governance yang signifikan secara parsial terhadap kinerja keuangan pada perusahaan manufaktur di Indonesia.

Pengaruh Keputusan Investasi Terhadap Kinerja Keuangan. Hasil penelitian menunjukkan bahwa keputusan investasi berpengaruh tidak signifikan terhadap kinerja keuangan. Keputusan investasi yang digunakan dalam penelitian ini adalah investment opportunity set (IOS). Investment Opportunity Set (IOS) lebih ditekankan pada opsi investasi di masa depan. Pada perusahaan manufaktur pasti lebih memperhatikan ketersediaan persediaan, karena persediaan yang jumlahnya sedikit akan menyebabkan kerugian jika sewaktu-waktu terjadi penjualan yang meningkat. Sedangkan keputusan investasi bukan hanya pada persediaan tetapi dapat dilakukan pada asset lancar lain, missal kas dan piutang, dan asset tetap, oleh karena itulah maka keputusan investasi tidak berpengaruh terhadap kinerja keuangan.

Pengaruh Keputusan Pendanaan Terhadap Kinerja Keuangan. Hasil penelitian menunjukkan bahwa keputusan pendanaan berpengaruh signifikan terhadap kinerja keuangan. Sumber dana ada dua, yakni dari luar perusahaan yang berupa hutang dan dari dalam perusahaan yang berupa modal sendiri. jika lebih banyak berasal dari hutang maka kita akan menanggung beban bunga yang tinggi, beban bunga yang tinggi akan berimbas pada penurunan laba perusahaan. tetapi sebaliknya jika lebih sedikit hutang akan meningkatkan perolehan laba perusahaan. Proksi yang digunakan pada keputusan pendanaan dalam penelitian ini adalah time interest earned (TIE), yang mana diperoleh dari pembagian laba sebelum pajak terhadap beban bunga (keuangan), maka otomatis beban bunga tinggi laba turun atau bahkan bisa rugi dan sebaliknya beban bunga yang rendah laba akan meningkat.

Pengaruh Kebijakan Dividen Terhadap Kinerja Keuangan. Hasil penelitian menunjukkan bahwa kebijakan dividen berpengaruh tidak signifikan terhadap kinerja keuangan. Dividen seharusnya dibagi berdasarkan laba yang diperoleh oleh perusahaan, tetapi pada kenyataannya 
yang terlihat dari laporan keuangan tahunan yang dipublish pada Bursa Efek Indonesia, masih ada perusahaan yang membagikan dividen meskipun kondisi rugi. Artinya masih ada perusahaan yang berpendapat bahwa pada kondisi laba ataupun rugi mereka harus tetap membayar dividen dengan tujuan agar para pemegang saham tetap mau menanamkan modalnya pada perusahaan. Artinya juga sebesar apapun dividen yang dibagikan tidak memberikan arti kinerja keuangan yang baik atau buruk.

Pengaruh Good Corporate Governance Terhadap Kinerja Keuangan. Hasil penelitian menunjukkan bahwa good corporate governance berpengaruh signifikan terhadap kinerja keuangan. Pada tiap perusahaan terdiri dari dua pihak, pihak pemilik (penanam modal) dan pihak manajemen (pelaksana). Kedua belah pihak pasti memiliki tujuan dan harapan yang sama, yakni meningkatkan kesejahteraan, oleh karenanya perlu tata kelola yang baik agar terdapat transparansi antara pemegang saham dan manajemen. Apabila mekanisme good corporate governance tersebut dapat berjalan dengan efektif dan efisien, maka seluruh proses aktivitas perusahaan akan berjalan dengan baik, sehingga hal-hal yang berkaitan dengan kinerja perusahaan baik yang sifatnya kinerja finansial maupun non finansial akan juga turut membaik.

Pembahasan Hasil Pengujian Hipotesis Kedua. Pembahasan ini berkaitan dengan hasil pengujian terhadap hipotesis kedua yang menyatakan bahwa terdapat pengaruh keputusan keuangan dan good corporate governance yang signifikan secara simultan terhadap kinerja keuangan pada perusahaan manufaktur di Indonesia. Hasil penelitian menunjukkan bahwa keputusan keuangan dan good corporate governance secara simultan berpengaruh signifikan terhadap kinerja keuangan. Keputusan investasi adalah keputusan perencanaan dan pengambilan keputusan mengenai pengeluaran/penggunaan dana perusahaan untuk jangka waktu cukup panjang. Keputusan investasi berkaitan dengan keputusan pendanaan, keputusan mengenai penentuan sumber atau asal dana yang akan digunakan dan perimbangan pendanaan yang optimal. Sumber atau asal dana yang digunakan untuk operasional perusahaan, dari dalam dan dari luar perusahaan.

Perolehan laba yang besar atau kecil akan berakibat pada kebijakan besaran dividen yang akan dibayarkan pada para pemegang saham. Dan kebijakan pembagian dividen menjadi sinyal kinerja keuangan perusahaan. Keputusan investasi, pendanaan, dan kebijakan dividen, semua kegiatan dalam perusahaan harus selalu mendapat persetujuan dari para pemegang saham. Oleh karena itu perlu suatu system terkait dengan tata kelola perusahaan yang baik atau good corporate governance. Pelaksanaan dari keempat hal tersebut dengan baik berpengaruh terhadap kinerja keuangan perusahaan.

Pembahasan Hasil Pengujian Hipotesis Ketiga. Pembahasan ini berkaitan dengan hasil pengujian terhadap hipotesis ketiga yang menyatakan bahwa terdapat pengaruh keputusan keuangan dan good corporate governance secara parsial signifikan terhadap ukuran perusahaan. Hasil penelitian menunjukkan bahwa:

Pengaruh Keputusan Investasi Terhadap Ukuran Perusahaan. Hasil penelitian menunjukkan bahwa keputusan investasi berpengaruh secara signifikan terhadap ukuran perusahaan. Pengaruhnya adalah positif, artinya ukuran perusahaan akan meningkat sebesar rupiah asset yang diinvestasikan. Investasi terhadap asset lancar maka akan meningkatkan jumlah total asset. Pengadaan asset tetap juga berpengaruh sekali terhadap total asset. Intinya investasi pada seluruh asset akan sangat berpengaruh terhadap ukuran perusahaan. 
Pengaruh Keputusan Pendanaan Terhadap Ukuran Perusahaan. Hasil penelitian menunjukkan bahwa keputusan pendanaan berpengaruh secara tidak signifikan terhadap ukuran perusahaan. Keputusan hutang dalam penelitian ini menggunakan proksi time interest earned yang mana lebih memperhatikan pada beban bunga atau beban keuangan, yang tercatat dalam laporan laba rugi, artinya beban bunga berpengaruh terhadap perolehan laba. Bunga yang tinggi akan menurunkan pada perolehan laba, dan sebaliknya bunga yang rendah akan meningkatkan perolehan laba.

Pengaruh Kebijakan Dividen Terhadap Ukuran Perusahaan. Hasil penelitian menunjukkan bahwa kebijakan dividen berpengaruh secara tidak signifikan terhadap ukuran perusahaan. Dividen akan terkait dengan besarnya pajak yang akan dibayar oleh pemegang saham. Akhirnya tidak semua pemegang menyukai dividen. Artinya tanpa membayar dividenpun perusahaan mampu menarik minat calon investor untuk berinvestasi pada perusahaannya. Dana yang ditanamkan oleh investor merupakan saham modal yang mampu meningkat total asset atau ukuran perusahaan. Hal ini membuktikan bahwa tanpa membayar dividenpun perusahaan mampu meningkatkan total asset.

Pengaruh Good Corporate Governance Terhadap Ukuran Perusahaan. Hasil penelitian menunjukkan bahwa good corporate governance berpengaruh secara tidak signifikan terhadap ukuran perusahaan. Hal tersebut disebabkan karena para investor beranggapan bahwa perusahaan yang dipublis pasti akan bekerja secara hati-hati terutama dalam mengelola dana para pemegang saham dan kreditur. Sebenarnya pemerintah juga melindungi kepentingan para pemegang saham dan kreditur. Hal tersebut diatas yang menyebabkan good corporate governance tidak berpengaruh terhadap ukuran perusahaan.

Pembahasan Hasil Pengujian Hipotesis Keempat. Pembahasan ini berkaitan dengan hasil pengujian terhadap hipotesis keempat yang menyatakan bahwa terdapat pengaruh keputusan keuangan dan good corporate governance yang signifikan secara simultan terhadap ukuran perusahaan. Hasil penelitian menunjukkan bahwa keputusan keuangan dan good corporate governance secara simultan berpengaruh signifikan terhadap ukuran perusahaan. Keputusan keuangan yang terdiri dari keputusan investasi, keputusan pendanaan, kebijakan dividen harus direncanakan dan dipertimbangkan dengan sebaik-baiknya. Pelaksanaan keputusan keuangan ini tidak terlepas dengan tata kelola perusahaan yang baik atau good corporate governance, karena dengan good corporate governance maka pihak manajemen perusahaan akan bekerja secara hati-hati agar mampu memenuhi keinginan atau kesejahteraan pemegang saham dan sekaligus pihak perusahaan. Semakin baik pelaksanaan keempat variabel tersebut maka semakin mampu meningkatkan ukuran perusahaan.

Pembahasan Hasil Pengujian Hipotesis Kelima. Pembahasan ini berkaitan dengan hasil pengujian terhadap hipotesis kelima yang menyatakan bahwa ukuran perusahaan memoderasi keputusan keuangan dan good corporate governance secara signifikan terhadap kinerja keuangan. Hasil penelitian menunjukkan bahwa ukuran perusahaan memoderasi keputusan keuangan dan good corporate governance secara tidak signifikan terhadap kinerja keuangan. Ukuran perusahaan tidak memperkuat pengaruh keputusan investasi terhadap kinerja. Kemungkinan hal tersebut disebabkan karena perusahaan lebih banyak berinvestasi pada asset tetap bukan asset lancer. Ukuran perusahaan tidak mampu memoderasi pengaruh keputusan pendanaan terhadap kinerja, karena keputusan pendanaan dalam penelitian ini lebih menekankan pada beban bunga/beban keuangan. Ukuran perusahaan bukan penguat hubungan antara kebijakan dividen dengan kinerja keuangan. Kemungkinan hal ini disebabkan laba ditahan yang tidak dibagikan sebagai dividen, tidak digunakan untuk 
pengadaan asset lancar tetapi hanya digunakan untuk pengadaan asset tetap. Ukuran perusahaan justru tidak mampu memoderasi pengaruh good corporate governance terhadap kinerja keuangan. Hal tersebut kemungkinan disebabkan dana yang diterima dari pemegang saham tidak diinvestasikan pada asset lancar tetapi terfokus pada asset tetap.

\section{KESIMPULAN}

Berdasarkan hasil penelitian dan pembahasan, maka dapat disimpulkan bahwa, secara parsial hanya keputusan pendanaan dan good corporate governance yang berpengaruh secara signifikan terhadap kinerja keuangan. Selanjutnya hanya keputusan investasi yang berpengaruh signifikan terhadap ukuran perusahaan. Secara simultan keputusan keuangan (yang terdiri dari keputusan investasi, keputusan pendanaan, dan kebijakan dividen) dan good corporate governance berpengaruh secara signifikan terhadap baik kinerja keuangan maupun ukuran perusahaan. Akan tetapi ukuran perusahaan tidak mampu memoderasi secara signifikan keputusan keuangan dan good corporate governance terhadap kinerja keuangan.

\section{DAFTAR PUSTAKA}

Adediran, S A, And S O Alade. 2013. "Dividend Policy And Corporate Performance In Nigeria." American Journal Of Social And Management Sciences (Samuel 1989): 7177.

Ajanthan, A. 2013. "Impact Of Corporate Governance Practices On Firm Capital Structure And Profitability: A Study Of Selected Hotels And Restaurant Companies In Sri Lanka." Research Journal Of Finance And Accounting 4(10): 2222-2847.

Argo, Jenji Gunaedi. "The Influence Of Investment Decision, Capital Decision And Financial Performance On The Company Values In Manufacture Company Registered In Indonesian Stock." : 1-12.

Isbanah, Yuyun. 2015. "Pengaruh Esop , Leverage , And Ukuran Perusahaan Terhadap Kinerja Keuangan Perusahaan Di Bursa Efek." Jurnal Riset Ekonomi Dan Manajemen 15(1): 28-41.

Keown, Arthur J, John D Martin, J William Petty, And David F Scott. 2008. "Manajemen Keuangan: Prinsip Dan Penerapan.” Edisi Kesepuluh. Jakarta: Pt Indeks.

Keuangan, Pengaruh Kinerja Et Al. 2017. "( Studi Empiris Pada Perusahaan Property Dan Real Estate Yang Terdaftar Di Bursa Efek Indonesia ( Bei ) Periode Tahun 2012-2015 )." 7(1).

Kurniawan, Wahyu. 2012. Corporate Governance Dalam Aspek Hukum Perusahaan. Grafiti.

Ng'ang'a, Kiuru, Charles. 2014. “The Relationship Between Dividends And Firm's Performance: A Case Study Of Listed Firms In The Nairobi Securities Exchange For The Period 2006 - 2012." Doctoral Dissertation, United States International UniversityAfrica.

"No Title." 2016.

Nofitasari, Nunung, Kertahadi, And Fransisca Yaningwati. 2016. "Pengaruh Good Corporate Governance Terhadap Kinerja Keuangan Dan Efeknya Terhadap Nilai Perusahaan ( Studi Pada Badan Usaha Milik Negara Yang Terdaftar Di Bursa Efek Indonesia Periode 2012-2014 )." Administrasi Bisnis 33(1): 146-53.

Putra, Andrie, Dan Royhisar Martahan Simanungkalit. (2014). The Impact Of Implementation Good Corporate Governance To Firm Value (Evidence From Indonesia Public Banking Sector). Review Integrative Business \& Economics Research. Vol 4(1).

Saifi, Muhammad, Dkk. (2013). The Effect Of Corporate Governance And Investment Opportunity Set On Capital Structure, Dividend Policy, And Firm Performance (A 
Study On Go-Public Manufacturing Companies In Indonesia Stock Exchange). International Journal Of Management And Administrative Sciences (Ijmas) (Issn: 22257225) Vol. 3. No. 02. (53-63).

Tajang, Norzaleha Binti Ambo. (2011). The Factors Affecting The Financial Performance In Malaysia Palm Oil Industry. Faculty Of Economic And Business, Universiti Malaysia Sarawak.

Harmono. (2016). Manajemen Keuangan Berbasis Balanced Scorecard Pendekatan Teori, Kasus, Dan Riset Bisnis. Jakarta. Bumi Aksara.

Keown, A. J., Martin, J. D., Petty, J. W., \& Scott, D. F. (2008). Manajemen Keuangan: Prinsip Dan Penerapan. Edisi Kesepuluh. Jakarta: Pt Indeks.

Kurniawan, W. (2012). Corporate Governance Dalam Aspek Hukum Perusahaan. Grafiti. 